\title{
The graphic speech of the Brand
}

In visual identity context, graphic designer has the difficult task to optimize the emission of an intangible message, and give it graphical form, trying to communicate complex information to the audience by the most understandable way possible.

During graphic signs selection, the designer's intention attends to the Corporate Visual Identity goals concerning the public's perception, in order to control the Corporate Image. In a globalized and increasingly digital world, small businesses appear to be large, markets are broader and brand communication strategies appear to be on the customization and fascination of the masses.

However, in Portuguese context it isn't strange to find companies that do not know themselves, they haven't done a work of inner reflection on their values, mission and goals. In this system, the designer has assumed greater responsibilities in brand communication process, both in defining strategies and in graphic codes selection and orientation. This paper is based on literature review, seeking to contribute to knowledge about the graphic designer role during the materialization of brand speech, including how the graphic signs personality expression in a cultural context.

keywords brand mark, connotation, brand personality, culture, encode

\section{Introduction}

The notion of brand presents some complexity for bringing together an intangible dimension (culture, values and brand image) and a tangible one (Brand mark).

Following the premises of Communication Design, the designer is the interface optimizer, the mediator between the corporate messages from the company to the audience. The designer concerns about the Corporate Visual Identity project, selecting and manipulating the inter-subjective codes required for the proper decoding in a given context. The Corporate Visual Identity project refers to a system of integrated graphic signs that gain a new semantic meaning when drawn together. From the Design's perspective, the expression of Signs of Corporate Identity determines the graphic-semantic positioning of the brand according to notions of value.

Designing a brand is not a task to chance. Brands have to ensure the distinction, differentiation and recognition. As stated by Zimmermann (1998, 84), opposing to being fashionable, which is to share the same language with a group, "to have style it is to be unique, to be different". In the scope of Corporate Visual Identity, the concept of style refers to "a quality or a characteristic way of expressing itself" (Schmitt \& Simonson, $1998,111)$, and with this way of becoming public it could use all the expressions of communication design. 
theme 3

identity

Figure 1.

Costa (2010, p.71) and Mendenhal

(1990, p.7) strand 2

localities / globalities

\section{The Brand as a cultural interface}

The authors Haig \& Harper (1997) ensure that Visual Identity's style is directly related to credibility, which, moreover, is a trust factor that increases its persuasive power. This notion of corporate credibility is important, because while people as consumers prefer to relate with the brands that are more trustworthy because they are seen as the most professional, most competent and most knowledgeable in the subject

"the logotype should serve as the credible voice of the company's graphics program. But, once again, as it happens with a person, the logotype must be a believable representation of the business it symbolizes to be effective" (Haig \& Harper, 1997, p.26).

Brand marks have the task to connote quality and warranty, origin and ownership, providing a graphic speech, a style expressing its unique identity. To do this marks are inspired by real things, myths, legends, ideas, human behaviours, copied heraldry, the humour, the surreal, are naïfs, serious, geometric or technological, etc. (Costa, 1987).

Has explained by Costa (2010) some brands have adopted a popular and far from an intellectual or industrial logic discourse, taking a more embodied and emotive communication, through humour, casualness, caricature or imagination. Mendenhal (1990) explains that in the late nineteenth century, brands have recognized the potential of the personification of their products.

By adopting a popular language, brands allow themselves to connect with a larger audience, as for example Google and Yahoo.
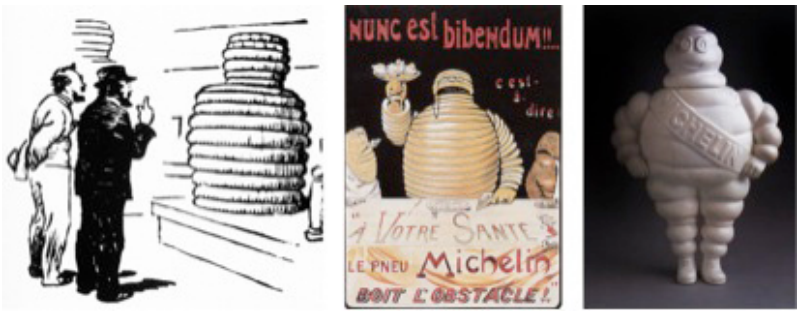

To McCrea (1994) characters and mascots are a symbolic extension of the human imagination and fantasy, based on traditions and myths, often related to the fantastic, invoking emotional responses that a logo could not, at that stick to memory and help give trust and credibility. But, according to Costa (1987, p.72)

"...brands are not restricted to copy reality, sometimes they introduce new a rhetoric of persuasion and other times formal cogency. The entire range of figuration, all resources of expressiveness, all cultural reflections of every age - and the most refined techniques of seduction and memorization - are in the commercial imagery."

Schroeder (2009, p.124) says that brands are no longer only mediators of cultural meaning, they are the result of the associations between the traditions and conventions of culture and the production and consumption. 
"...brands exist as cultural, ideological, and sociological objects, then understanding brands requires tools developed to understand culture, ideology, and society, in conjunction with more typical branding concepts, such as brand equity, strategy, and value."

According Maasik \& Solomon (1994), the characters cause a strong impact on collective memory because they have denotative (they say what they are) and connotative meanings (they suggest or appear some values). This graphic use of drawing consist in use connotative meanings associated to the strengthening of the collective imagination and seems to have predominant impact of Brand mark in memory.

Olins (1989, p.67) states that corporate style is a tool used by organizations to stand out and to differentiate themselves from its competitors, so that

"when an organization within the industry has a strong personality and wants to demonstrate its individuality to those with whom it deals, there is no clearer, more powerful statement than that demonstrated by a strong individual visual style."

\subsection{Corporate Culture and Identity}

Tajada (2008) believes that corporate culture is the dominant set of beliefs and values of the organization, corporate philosophy, standards and characteristic of the working groups habits, traditions and behaviours. But to Villafañe (1993), the definition of corporate culture is more evident, the author believes that it is the process of social construction of self-identity, that is, the appropriation of meaning (or new meanings). For the author, the identity comes from the history of the company, the business plan and corporate culture.

The concept of corporate culture can be subdivided into the realistic, idealistic and ambitious plans, which are related to the mission and conditions of identity and is a natural consequence from acting and communication between groups of people over time in a context work (Tajada, 2008).

Constituting itself as a way to think and act in a group, the corporate culture contributes to the formation of identity, that is, "... to the organization or parts of it have the sense of being as a consistent and specific being, that assumes his history and place in society" (Kapferer, 1991, pp.30-31).

In this sense, the corporate identity is a set of attributes assumed as their own by the organization, which constitutes the "identity discourse." It is developed inside the organization, as with an individual. Corporate Identity is a complex picture, once a set of visions is not necessarily similar. Each social subject has a notion of what it is, and the way it pretends to be seen.

\subsection{The Brand Personality}

Aaker (1997) proposed the "Dimensions of Brand Personality" as "the set of human characteristics associated with a brand" caused by direct or indirect contact between the audience and the brand (Plummer, 1985, quoted by Aaker, 1997). 
theme 3

identity

Figure 2.

Brand marks adaptation to different cultures (Strunck, 2007, pp.32-33) strand 2

localities / globalities

Kapferer (2012) considers that the definition of brand personality by Aaker (1997) is too broad to include any intangible attribute as intellectual abilities, gender and social class and maintains the model of "Brand Identity Prism (1992)", which is based on knowledge of psychology and is based on the design project.

In its proposal, Kapferer (2012) presents six dimensions that shape the personality and brand identity: 1 - Physical (objective characteristics, symbols and attributes); 2 Personality (subjective characteristics, character and attitude); 3 - Culture (set of values that define the context in which the brand grows) 4 - Relation (beliefs and associations and how they will interconnect with the public); 5 - Reflection of the public (creating value through stereotypes aspirations of the public), and 6 - self-image (the way the public sees himself and how this relates to the brand perception).

According to Azoulay \& Kapferer (2003), the brand personality is a concept that consists in assigning a set of human characteristics to the brand, such as values, age, emotions, behaviours, attitudes and beliefs. The brand personality fosters lasting relationships between the issuer and the audience because it relies on the communication of identity on a symbolic level recognizable by the public, which seeks to identify objects with archetypal, related with styles of life (Martins, 1999)

\section{The Brand mark as cultural container}

The Signs of Corporate Visual Identity differ with the culture of the different stakeholders (mainly the company and its audience). This practice is most evident when comparing the Brand marks of the same company in different countries. Strunck (2007, p.32) believes that "it is not excessively to remember that the associations we establish with brands result from our cultural repertory"2.

It's common that internationally renowned brands suffer adaptations to suit cultural codes.
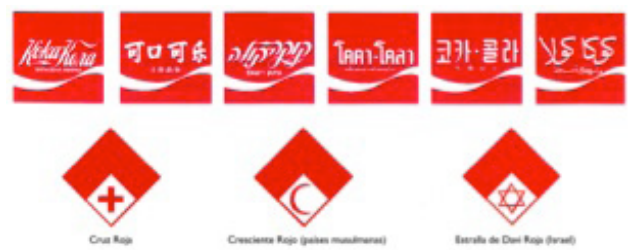

Since 1968 Mitsubishi Electric's company has used two styles and positioning with different Brand marks. But it was in 1985 when they introduce a Brand mark composed by a blue logo, no symbol and a slogan intended to Japan to convey a certain individualism the Mitsubishi Group, while the other variant, destined for other audiences, keeps the symbol in red and black logo and slogan appear only 2001.

However, concerning the visual adaptation strategies to different cultures, Schmitt \& Simonson (1998, p.116) consider that the form of logos is a central issue for the IVC codes

${ }^{2}$ Free Translation from: "Nunca é demais lembrar que as associações que estabelecemos com as marcas são criadas com base em nosso reportório cultural. É muito comum que marcas usadas internacionalmente sofram adaptações para se adequarem a tipos de escrita local." 
because "unlike the names, forms cross borders culture with relative ease."

International brands seem to have understood the serious consequences that they may

\section{MITSUBISHI \\ 三菱㫣譏 \\ Changes for the Better}

Figure 3.

Mitsubishi Brand

mark adaptation to

different cultures.

suffer from the incorrect encoding of Brand graphic signs. Strunck (2007) gives the example of Nike Air series, whose letters were in flames therefore some Arab countries have not agreed to because it was mistaken for the word "Allah", which was considered an offense because the name of God can not appear in a shoe.

Herrera Fernández (2004, p.3) explains how the visual identity signs can receive ideological attributes to represent countries, regions or ideas and exemplifies that "obviously, the use of Basque letter is a real attempt by a social and political sector, to create a particular visual style to represent the nationalist spirit in order to build a distinct cultural entity, specified and differentiated, strengthening and establishing a differentiated state."

As we have observed, often the appropriation of graphic signs implies its connotative recoding through its association and consistent use related to a specific behaviour (Herrera Fernández, p. 2004).

But Brand marks are also changing their shape throughout time, modified; perhaps to help business strategy or to fit the visual codes of a particular time and society, as says Gonzáles Solas (2004, pp.127-128) "...the cleaning of the signs has been progressive, as seen in historical sequence logos of various entities."

\section{Conclusion}

Trademarks remain the essential principle of distinction, identification and differentiation of an entity that is represented by it.

The complexity of visual language is simultaneously its wealth, allowing flexibility for countless purposes and cultural contexts. Despite its dependence on the culture and context of use, the amount of inter-subjective codes makes it the most complex and close to a universal language.

Although the visual language is closer to a universal language, the expression and design of the graphic signs approaches them to a particular culture, time or specific context. The signs are mutable because they result from human social and cultural interaction over time. Everything has meaning, but the question is whether the semantic meaning corresponds to the objectives of the brand.

\footnotetext{
${ }^{3}$ Free Translation from: "...la limpieza de los signos ha sido progresiva, como puede apreciarse en las secuencias históricas de los logotipos de diversas entidades..."
} 


\section{References}

Aaker, A. L. (1997) Dimensions of Brand Personality, Journal of Marketing Research, vol. 34, no 3 August, pp. 347-356.

Azoulay, A. and Kapferer, J-N (2003) Do brand personality scales really measure brand personality? Journal of Brand Management. vol. 11, no 2 November, p.143-155.

Costa, J. (2010) La marca: Creación, diseño y gestión, Cidade do México: Editorial Trillas. Costa, J. (1987) Imagen Global, Enciclopedia del diseño, Barcelona: Ediciones CEAC. Gonzáles Solas, J. (2004) Identidad Visual Corporativa: La imagen de nuestro tiempo, Editorial sinTesis.

Haig, W. L. and Harper, L. (1997) The power of logos: how to create effective company logos, New York: International Thomson Publishing Company.

Hartwell, M. and Chen, J. C. (2012) Archetypes in Branding: A Toolkit for Creatives and Strategists. Blue Ash, Ohio: HOW Books.

Herrera Fernández, E. (2004) - La letra Vasca: Etnecidad y cultura tipográfica. Revista Visual. Madrid: Blur Ediciones. Nº109 Julio (2004), p-1-7.

Kapferer, J-N (1991) Marcas: Capital da Empresa, Lisboa: Edições Cetop.

Kapferer, J-N (2012) The New Strategic Brand Management Advanced insights and strategic thinking, 5th edition, London: Kogan Page.

Martins, J. (1999) A Natureza Emocional da Marca: Como escolher a imagem que fortalece a sua marca, São Paulo: Negócio Editora.

McCrea, Adams (1994) Advertising Characters: The Pantheon of Consumerism. In Maasik, S. and Solomon, J. (ed.) Readings on Popular Culture for Writers, 3rd edition, Boston: Bedford Books.

Olins, W. (1989) Corporate Identity: Making Business Strategy Visible through design, London: Thames and Hudson.

Schmitt, B. and Simonson, A. (1998) Marketing y estética: la gestión estratégica de la marca, la identidad y la imagen, Bilbao: Ediciones Deusto.

Schroeder, J. E. (2009) The Cultural Codes of Branding, Marketing Theory, vol. 9 no 1, p.123-126.

Strunck, G. (2007) Como criar identidades visuais para marcas de sucesso, 3rd edition, Rio de Janeiro: Rio Books.

Tajada, L. Á. S. de (2008) La auditoria de la imagen de empresa: métodos y técnicas de estudio de la imagen, Madrid: Editorial Sintesis.

Villafañe, J. (1993) Imagen positiva: Gestión estratégica de la imagen de las empresas, Madrid: Ed. Pirámide.

Zimmermann, Y. (1998) Del Diseño, Barcelona: Editorial Gustavo Gili. 
